\title{
Historicidade da tradução em Benjamin e um estudo de caso
}

\author{
[Historicity of translation on Benjamin and a case study]
}

http://dx.doi.org/10.11606/1982-8837223630

\section{Rodrigo Octávio Cardoso ${ }^{1}$}

\begin{abstract}
The act of translating seems to bring about difficulties demanding multiple solutions that, while contingent, may have long lasting political and historical implications. Luther's Bible translation is a marked example of the historical force of translation and of the polemics concerning its form. In "The Task of the Translator", Benjamin proposes two distinct temporalities for the life of a literary text and that of its translations, starting a debate regarding the different historical times present in a text, and in its relations with different languages. Departing from these considerations, I propose the discussion of some concrete difficulties experienced in the translation of quotations from a literary work in a critical text by Walter Benjamin, "Am Kamin", a text that develops Benjamin's theory of the novel. How can I translate, today, quotations made by Benjamin of a 1920's German translation of Arnold Bennet's 1908 novel The old wives tale, with its early 19th century narrator, not yet translated into Portuguese? Finally, I present "Am Kamin" translated into Portuguese.
\end{abstract}

Keywords: Historical translation; Historicity of translation; "Am Kamin".

Resumo: A tradução parece trazer dificuldades que exigem soluções diversas que, escolhidas contigencialmente, podem ter implicações históricas e políticas duradouras. A tradução da Bíblia por Lutero é um exemplo marcante da força histórica da tradução e das polêmicas quanto à sua forma. Em "A Tarefa do Tradutor", Benjamin estabelece duas temporalidades distintas para a vida de um texto literário e a de suas traduções, instaurando um debate a respeito dos diferentes tempos históricos que atravessam um texto, em sua relação com as diferentes línguas. A partir dessas considerações, nos propomos a discutir certas dificuldades concretas experienciadas na tradução de citações de uma obra literária dentro de um texto crítico de Benjamin, Am Kamin, um dos textos em que desenvolve sua teoria do romance. Como traduzir hoje as citações que Benjamin faz do romance The old wives tale de Arnold Bennet, citações da tradução para o alemão dos anos 1930, de um texto inglês de 1908 que emula um narrador do início do século XIX, e que não foi ainda traduzido para o português? Por fim, apresento o texto traduzido, "À Lareira".

Palavras-chave: Tradução histórica; Historicidade da tradução; “À Lareira”.

\section{Exórdio: uma tradução histórica}

É quase impossível obter alguma coisa como um consenso quando se fala de tradução. Se entregarmos um mesmo texto a vários tradutores diferentes para que o traduzam,

\footnotetext{
${ }^{1}$ Universidade Estadual de Campinas, Rua Sérgio Buarque de Holanda, 571, Campinas, 13083-859, Brasil. E-mail: rodrigooabcardoso@gmail.com
}

(cc) BY-NC

Pandaemonium, São Paulo, v. 22, n. 36, jan.-abr. 2019, p. 30-50 
CARDOSO, R. - Historicidade da tradução em Benjamin

certamente receberemos tantos textos traduzidos diferentes quanto haviam tradutores. Isso não somente porque cada um terá sua proposta ligeiramente diferente a respeito da organização das frases, da escolha vocabular, de pontuação, mas também porque haverá diversas concepções a respeito do que é tradução e, mesmo, diferentes interpretações sobre o original.

Uma vez que todas as línguas se delimitam apenas pelo contato com outras línguas das quais se diferenciam, pode-se pensar que o problema da tradução é tão antigo quanto o problema da diversidade de línguas. Poderíamos imaginar a situação de risco e de prestígio de uma pessoa que dominasse as línguas de duas tribos em conflito em uma antiguidade pré-histórica, seu papel crucial na diplomacia entre os grupos, a gravidade de uma eventual escolha infeliz ou apressada na tradução - a determinação histórica da extinção de uma delas, sua coexistência pacífica ou belicosa. De fato, com a escrita, a tradução ganhou mais relevo e se tornou mais evidente, uma vez que a sua fixação torna possível sua crítica e a comparação com outras versões do texto. Não é pouco observar que o livro que durante séculos orientou política e moralmente a formação da Europa e sua posterior expansão imperial tenha sido uma tradução. Desde o final do século IV a Bíblia, livro sagrado e texto base do cristianismo, circulava oficialmente na forma de sua tradução para o latim dos seus vários livros compostos (alguns já a partir de traduções, suspeita-se) em hebraico, aramaico e grego, ao longo de cinco mil anos da história do povo judeu ${ }^{2}$. E uma vez que o latim era cada vez menos conhecido e dominado entre a população comum, essa tradução de São Jerônimo, conhecida como Vulgata, precisava sempre reiteradamente ser traduzida pelos pregadores para os diferentes vernáculos, até que Lutero fizesse a primeira tradução escrita completa para uma língua vernácula, o alemão, fixando o texto naquela língua, e fixando a própria língua através daquele texto - uma vez que a língua alemã não possuía uma formalização de sua forma escrita, a tradução de Lutero acabou exercendo esse papel, tornando-se o padrão da língua alemã que, à parte algumas reformas e modificações, estabeleceu as bases do alemão moderno usado até hoje.

A tradução de São Jerônimo e de Lutero tornaram-se, problematicamente, paradigmas para a tradução nas culturas herdeiras do cristianismo. Digo problematicamente porque as concepções sobre a verdade, a origem, a interpretação e o

\footnotetext{
2 cf. “Observações”. In: Bíblia de Jerusalém, p. 13

Pandaemonium, São Paulo, v. 22, n. 36, jan.-abr. 2019, p. 30-50
} 
CARDOSO, R. - Historicidade da tradução em Benjamin

significado do texto, como eram compreendidas na mentalidade judaico-cristã acabaram sendo transmitidas e imiscuídas nas noções e debates sobre a tradução que se seguiram. É preciso lembrar que a tradução de Lutero foi um marco na história das línguas europeias e da tradução, bem como da escrita, sendo o primeiro livro produzido em massa, poucas décadas após a invenção da imprensa. Para Benedict Anderson (2008), esse foi um acontecimento determinante também na história da formação das nações modernas, uma vez que a produção em massa da Bíblia na eclosão do capitalismo de imprensa, em suas traduções vernáculas, seguindo o impulso da Reforma Luterana, tornou necessárias as padronizações linguísticas que ordenaram a identificação de diversas variedades linguísticas em torno de comunidades nacionais limitadas. A tradução de Lutero também protagonizou uma fissão na história das religiões, como um dos símbolos mais importantes da Reforma protestante. A Igreja Católica, ao contrário, continuou usando predominantemente o latim em seus ritos até o Concílio Vaticano II nos anos 1960. Assim, o método de tradução de Lutero e suas escolhas particulares foram centro de um debate acalorado não apenas linguístico, mas também teológico, colocando-se na base de uma doutrina e uma dogmática religiosa.

Em um célebre texto para os estudos da tradução, a "Sendbrief vom Dolmetschen" (Carta aberta sobre a tradução), Lutero responde, não sem ironia, a seus detratores "papistas", defendendo sua tradução. Alguns dos grandes problemas envolvidos na tradução em geral são aventados no texto. A polêmica central em torno da qual se estrutura a carta é a tradução da frase latina da vulgata "Arbitramur hominem iustificari ex fide absque operibus" para o alemão “Wir halten, daß der Mensch gerecht werde ohne des Gesetzes Werke, allein durch den Glauben" ("Sustentamos que o homem é justificado somente pela fé, sem as obras da lei"). O problema estaria no uso da palavra "allein" (somente), que não aparece na versão latina. Criticando a atitude dos que avaliam as suas escolhas sem levar em conta a enormidade de seu trabalho ("É fácil arar quando o campo está limpo" (LUTHER 2006: 103), Lutero defende sua escolha afirmando que seu texto em alemão não pode prender-se às palavras do texto original uma a uma: "Ao traduzir, esforcei-me em escrever um alemão puro e claro" (LUTHER 2006: 101). Na língua alemã, afirma, é essa a forma adequada, "quando usada para tratar de duas coisas, das quais uma é afirmada e outra negada, [ela] necessita da palavra sollum-allein, acompanhando a palavra nicht ou kein" (LUTHER 2006: 103). Mas, além da justificação linguística, de sua defesa da necessidade de falar a língua do povo ("man muss die Mutter im Hause, die 
CARDOSO, R. - Historicidade da tradução em Benjamin

Kinder auf der Gassen, den gemeinen Mann auf dem Markt drum Fragen und denselbigen auf das Maul sehen, wie sie reden" (LUTHER 2006: 104)), Lutero dá também uma justificação teológica, afirmando que sua escolha privilegia o sentido, a correta interpretação do texto, num ponto que se torna uma das principais diferenças entre a doutrina protestante e a doutrina católica, a salvação somente pela fé, pregada por Lutero e criticada pelos papistas:

Meu caro, precisamente São Paulo e nós desejamos tais escândalos e é esta a única razão por que pregamos tão fortemente contra as obras e insistimos somente na fé, a fim de que as pessoas se escandalizem, tropecem e caiam para poderem aprender e saber que não se santificam através de suas boas obras, mas somente pela morte e ressurreição de Cristo. (LUTHER 2006: 113).

Podemos recordar aqui da afirmação de Benjamin em "A tarefa do tradutor": "a tradução encontra-se [...] a meio caminho entre obra poética e doutrina" (BENJAMIN 2013: 113). Para Lutero, traduzir significa aqui não somente germanizar (verdeutschen), e menos ainda recompor poeticamente (nachdichten). $\mathrm{O}$ embate das línguas, das formas de visada entre original e texto traduzido aspira alcançar a verdade da palavra de Deus, a língua da verdade e a verdadeira língua, a que se refere Benjamin. Embora seu horizonte seja uma teologia judaica, e não cristã, não se pode subestimar o peso da tradução luterana para a história da língua materna de Benjamin.

A questão doutrinária implicada na polêmica da tradução utilizando o allein ("somente pela fé") foi mesmo capaz de gerar interpretações históricas tão radicais como a que atribui a essa doutrina a própria condição de possibilidade do desenvolvimento do “espírito" capitalista, por Max Weber (2004). Em sua obra mais célebre, o sociólogo sugere uma correlação entre desenvolvimento capitalista e a ética derivada da doutrina da predestinação, implicada na tradução de Lutero. Ora, se diferentes traduções de um mesmo livro são capazes de engendrar religiões e mesmo culturas econômicas distintas, não seria excessivo afirmar que se trata de textos distintos, embora suas histórias e territorialidades se entrelacem e sobreponham intimamente.

As traduções de Lutero não seguiam rigidamente uma única régua e compasso, mas procuravam adaptar-se às necessidades e exigências do texto: "Por outro lado, não abandonei completamente a letra, mas observei-a com grande cuidado junto a meus ajudantes, de maneira que, quando necessário, mantive-a e dela não me afastei tão livremente" (2006: 112). Desse modo, a tradução se torna, inevitavelmente, um jogo de recomposição de fragmentos, recordando a metáfora dos cacos de um vaso utilizada por 
CARDOSO, R. - Historicidade da tradução em Benjamin

Benjamin, ainda que certos textos específicos exijam uma maior ou menor aspecto de coesão e homogeneidade de acordo com o caráter do regime discursivo a que pertençam.

Como demonstra a "Sendbrief vom Dolmetschen”, a tradução de Lutero provocou imediatas reações e uma intensa polêmica, tanto por sua abordagem original da tradução, quanto pelas suas implicações doutrinárias, inscritas no contexto mais amplo da Reforma Protestante e as grandes transformações sociais, políticas e econômicas pelas quais passava a Europa naquele momento. Pelo papel que teve não apenas com relação à língua alemã, com a história das cisões do cristianismo e a formação das nações, mas também pelo debate que gera a respeito da prática e da historicidade das traduções, o trabalho de Lutero pode ser caracterizado, paradigmaticamente, como uma tradução histórica, “[a]quela que faz época enquanto tradução, aquela em que a tradução aparece como tal e tem acesso, assim, estranhamente, à posição de uma obra e não mais àquela de humilde mediação de um texto ele próprio histórico.” (BERMAN 2002: 57). A tradução histórica, tal como a concebe Berman, acede a tal estatuto não apenas por suas qualidades próprias ou pelo sentido de seu texto, mas porque responde a uma necessidade histórica maior, inscrevendo-se em seu tempo, afirmando algo sobre ele e sobre sua relação com a história do próprio texto, ou como afirma Benjamin, com sua vida. No caso de Lutero, menciono apenas três entre os muitos fatores que lhe dão esse estatuto: a originalidade de uma abordagem que associa o texto escrito e a língua ao modo de falar do povo; o momento histórico da invenção da imprensa e a formação das línguas nacionais (Anderson); e a relação entre as decisões tradutórias e o terremoto cultural e político promovido na Europa pela Reforma Protestante, com seus duradouros efeitos éticos, políticos e econômicos (Weber).

\section{Benjamin e a historicidade da tradução}

Se a tradução da Bíblia por Lutero fundamenta um amplo debate para a tradução, ela dificilmente pode ser tomada como um exemplo no que diz respeito à historicidade das traduções em geral. Muito mais frequentemente as traduções de um texto se tornam antiquadas e obsoletas e observamos década após década o surgimento de novas traduções para os textos mais canônicos. Diversos fatores contribuem para isso: a língua falada tem uma dinâmica própria e se transforma muito mais rápida e continuamente que a língua escrita e as modificações no padrão escrito parecem se seguir em ondas, com novas 
CARDOSO, R. - Historicidade da tradução em Benjamin

reformas ortográficas, padrões editoriais e formas de tratamento, hábitos culturais que se modificam, às vezes radicalmente, e os modos de falar e referências materiais dos textos podem se tornar incompreensíveis (FARACO 1998). Se esses fatores contribuem para o envelhecimento dos textos dentro da própria língua, podemos pensar em pelo menos duas razões para que esse distanciamento seja agravado nas traduções. Primeiro, como sugere Benjamin, um texto literário que alcança um certo valor canônico integra-se de tal forma em sua língua e cultura que acaba por influenciar mesmo suas formas de dizer e hábitos culturais, integrando-se às transformações históricas que aí ocorrem e constituindo uma memória que, mesmo que não imediatamente acessível, constitui um certo horizonte cultural histórico da língua. Além disso, a distância cultural que separa duas línguas em suas histórias distintas amplifica grandemente a separação entre um passado que constitui uma cultura e sua compreensão em outra língua e outra constituição de uma memória cultural, em uma estrutura de dissociação quiasmática.

Dessa forma, quanto à sua historicidade, as traduções mantêm uma complexa dialética com seus originais e com as línguas em jogo. Benjamin faz algumas afirmações interessantes a respeito em "A tarefa do tradutor", texto que escreve como prefácio à sua tradução de Fleurs du Mal, de Baudelaire. É interessante ter em mente que não se trata de uma tradução inédita, e que tampouco vingou, não tendo se tornado popular para os leitores do alemão. Os poemas de Baudelaire já haviam sido traduzidos pelo poeta Stefan George e essa tradução foi a que, de fato, tornou-se canônica, e assim permanece até hoje na língua alemã. Segundo Susana Kampff Lages (2007), as traduções de George eram fortemente domesticadoras, enquanto as de Benjamin, experimentais e estrangeirizantes, seguindo a orientação de Pannwitz, citado no célebre prefácio: “o erro fundamental de quem traduz é conservar o estado fortuito da sua própria língua, ao invés de deixar-se abalar violentamente pela língua estrangeira” (PANNWITZ apud BENJAMIN 2013: 118).

“A tarefa do tradutor" compartilha algumas preocupações teóricas com alguns outros textos produzidos mais ou menos na mesma época, no período que se seguiu imediatamente ao fim da guerra que envolveu toda a Europa entre 1914 e 1918. Alguns dos mais notáveis entre estes textos estão reunidos em edição brasileira em Escritos sobre mito e linguagem. Neles, retornam constantemente algumas noções sobre linguagem, destino e mito, envoltas em um tom místico e religioso que deixa transparecer o messianismo aberto de Benjamin, derivado de uma particular interpretação da teologia judaica. É importante perceber o grau de entrelaçamento entre essas noções para 
CARDOSO, R. - Historicidade da tradução em Benjamin

compreender a forma como a história emerge desses ensaios. A noção de destino, desenvolvida principalmente em "Destino e Caráter", mas também em "Para uma crítica da violência", "Dois poemas de Friedrich Hölderlin" e também em outros textos como "Das Glück des antiken Menschen", "Sokrates" e "Trauerspiel und tragödie", está profundamente enraizada em uma compreensão da relação entre vida como desenvolvimento histórico e linguagem. Neste sentido, vale lembrar que a palavra grega logos, frequentemente traduzida como razão, pode significar também palavra, verbo (como no evangelho de João: "No princípio era o verbo [logos]"), mas tem, além disso, o sentido de um discurso encadeado, de uma fala que possui um sentido. Este encadeamento, a sintaxe que concede sentido ao discurso, a lógica interna da linguagem, seria a própria matéria com que se concebe a noção de destino, seu tecido mesmo. Derivando essa noção das tragédias clássicas, Benjamin a associa a um nexo causal fundamentado no encadeamento de culpa e expiação. A língua carrega em si, desse modo, os encadeamentos que ordenam as possibilidades de uma justiça poética. Desse modo, no texto sobre Hölderlin, escreve: "Os deuses e os viventes estão vinculados entre si no destino do poeta por elos de aço" (BENJAMIN 2013: 28), e ainda "O mito é reconhecível na unidade interna de Deus e destino" (BENJAMIN 2013: 24). Assim, em um poema se dá “o entrelaçamento de relações no qual a identidade de cada ser singular é função de uma cadeia infinita de séries, através das quais o 'poetificado' se desdobra" (BENJAMIN 2013: 28). Ou seja, o poetificado, em sua relação com a língua, guarda as relações que identificam cada ser singular com todo o universo. Entretanto, se esse poetificado permanece inacessível, como forma interna do poema, ainda que em sua evidência imediata, é por causa da diversidade e fragmentaridade das línguas. Seu sentido último, como nos fragmentos do vaso reconstruído, seria reconstituído, como verdadeira justiça divina, na tradução entre todas as línguas, apontada em "Sobre a linguagem em geral e a linguagem do homem”, como retorno à língua adâmica, língua da pura nomeação, que não reparte o mundo segundo uma visada particular, mas fala da própria essência das coisas, identidade entre linguagem humana e linguagem das coisas mesmas. Como esclarece Jeanne Marie Gagnebin (2013), não se trata, aí, de um retorno utópico a um passado idílico da linguagem, em uma acepção crédula do mito do gênesis, mas de uma abordagem não utilitária da linguagem e desse messianismo aberto que enxerga nas pequenas frestas da história a possibilidade da chegada do messias, um messias cujas formas não se pode antecipar, mas que traria consigo a concretização da justiça. 
CARDOSO, R. - Historicidade da tradução em Benjamin

Retornando ao ensaio sobre a tradução, podemos compreender como as traduções se inscrevem na história, para Benjamin, por um entrelaçamento com essas concepções sobre a linguagem. A princípio, há uma relação entre a língua do original, seu modo de visar e o texto original, relação que é seu próprio vínculo vital, sua própria traduzibilidade, que exige a tradução, mas que permanece, ao mesmo tempo, intraduzível: "a relação que o teor estabelece com a língua é completamente diversa no original e na tradução. Pois, se no original eles formam certa unidade, como casca e fruto, na tradução, a língua recobre seu teor em amplas pregas, como um manto real." (BENJAMIN 2013: 111). Se há uma conexão vital no original, a metáfora do manto real não diz respeito apenas a uma artificialidade do texto em tradução, mas também ao acontecimento histórico que aí se concretiza. Como escreve Gagnebin, "[c]om a história intervém, portanto, a violência, o arbitrário, a estranheza, mas também, e inseparavelmente, a majestade de uma dinâmica que transforma cada língua supostamente 'natural' numa outra, mais alta que ela mesma." (2013: 24).

Benjamin aponta para o fato de que há uma limitação para as traduções, elas permanecem vinculadas ao seu tempo histórico e, se prolongam a vida do original, que se inscreve na história de sua língua, podem, por seu lado, tornar-se obsoletas e ultrapassadas. Para ele, o original deve às traduções uma forma de sua pervivência, da renovação de sua vitalidade através dos tempos, uma vez que a existência de uma tradução sempre resgata e renova a presença do original. Nas traduções "a vida do original alcança, de maneira constantemente renovada, seu mais tardio e mais abrangente desdobramento" (BENJAMIN 2013: 105). As traduções, assim, são capazes de desenvolver as potências do original, estendendo sua vida e fazendo-a florescer. Comentando o prefácio de Benjamin, Derrida afirma que esse prolongamento da vida e das potências do original não se restringe a uma reprodução, mas que "[t]al sobrevida [fortleben] dá um pouco mais de vida, mais que uma sobrevivência. A obra não vive apenas mais tempo, ela vive mais $e$ melhor, acima dos meios de seu autor." (DERRIDA 2002: 33, grifo de Derrida). Mas há uma diferença fundamental na forma de inscrição na história das línguas entre uma obra literária e suas traduções. Em sua pervivência, o original se modifica no seio da história de sua língua.

Assim como tom e significação das grandes obras poéticas se transformam completamente ao longo dos séculos, assim também a língua materna do tradutor se transforma. E enquanto a palavra do poeta perdura em sua língua materna, mesmo a maior tradução está fadada a desaparecer dentro da evolução de sua língua e a soçobrar em sua renovação. (BENJAMIN 2013: 108) 
CARDOSO, R. - Historicidade da tradução em Benjamin

Se levarmos em conta a força linguística e cultural de certas traduções consagradas no português, tais como "Ser ou não ser, eis a questão", "Eu é um outro" ou os termos Ego, Superego e Id da tradução Standard de Freud, que se tornou canônica, pese os diversos problemas de tradução que carrega, talvez essa afirmação de Benjamin pareça um pouco exagerada. De fato, um texto traduzido pode adquirir tal força e pervasividade em uma língua que se integre à sua história, transformando-se com ela e engendrando transformações. Basta lembrar do "allein durch den Glauben" de Lutero, extrapolando até mesmo seu território linguístico em sua força histórica. Na verdade, uma tradução particular pode determinar o desenvolvimento da recepção de uma obra em uma determinada língua de uma maneira consistente e duradoura, como também a própria tradução de Baudelaire por Stefan George que Benjamin vem contestar. Mas, ainda assim, podemos encontrar sentido na formulação benjaminiana. Se a poesia de Baudelaire se torna um cânone da língua francesa, repetindo sua influência e suas formas de dizer geração após geração, suas traduções para o português deverão fazer sentido em um determinado estado da língua e, conforme esse estado se modifique e a língua encontre novas conformações, as formas encontradas pelo tradutor poderão tornar-se estranhas, arcaicas ou obsoletas, e novas traduções serão sempre exigidas para renovar a recepção daquela obra neste idioma em constante transformação. ${ }^{3}$ É necessário, ainda, ponderar que a problemática da historicidade ou obsolescência das traduções não pode ser desconectada de questões relacionadas ao alcance e circulação dos textos em questão.

Com isso em vista, a necessidade histórica das traduções não pode ser explicada, em meio a essa constelação de textos benjaminianos, apenas por uma noção de reprodução do original. Não se trata de repetir na língua do tradutor o que o original fez em sua língua. Benjamin escreve: "a finalidade da tradução consiste, por último, em expressar o mais íntimo relacionamento das línguas entre si." (BENJAMIN 2013: 106). Este relacionamento íntimo das línguas, como argumentei acima, vincula-se à própria instauração da justiça na história. O tradutor entende-se, assim, como o historiador que busca na história das línguas alguma visada capaz de abrir uma fresta que possa dar lugar à justiça em seu presente. $\mathrm{O}$ original se utiliza das formas de visar de sua língua para

\footnotetext{
${ }^{3}$ Essa argumentação certamente poderia ser radicalizada se levarmos em conta a necessidade, em certas línguas, de traduzir um texto antigo para uma versão mais moderna da língua, compreensível para os seus contemporâneos, como é o caso das diversas traduções para o japonês moderno (como as de Yosano Akiko, Junichiro Tanizaki e Enchi Fumiko) de O Conto de Genji (Genji Monogatari), romance escrito no século XI, ainda sem tradução direta para o português.
}

Pandaemonium, São Paulo, v. 22, n. 36, jan.-abr. 2019, p. 30-50 
CARDOSO, R. - Historicidade da tradução em Benjamin

delinear seu objeto visado, de uma forma precisa e singular, o que não significa uma clareza absoluta na designação seu visado, que permanece ainda sempre envolto por sugestões e intuições. A tarefa do tradutor "consiste em encontrar na língua para a qual se traduz a intenção a partir do qual o eco do original é nela despertado" (BENJAMIN 2013: 112). A tradução, assim, embora evidencie um estranhamento entre aquele modo de visar do original e a língua da tradução, pode tornar manifestos, pelos modos de visar desta, novas feições do visado, aquelas que permaneciam na penumbra sob a luz da língua original: "Existe uma maturação póstuma mesmo das palavras que já se fixaram: o que à época do autor pode ter obedecido a uma tendência de sua linguagem poética, poderá mais tarde esgotar-se; tendências implícitas podem surgir como novas da forma criada." (BENJAMIN 2013: 108). Essa é a nova vida que a tradução dá ao original, um novo desenvolvimento de suas potências pela explicitação de um modo de visar antes apenas indicado ou intuído, mas também uma nova vida para a língua do tradutor, uma nova abertura e uma nova sintaxe que aí se inscreve: "[e]m nome da pura língua, o tradutor rompe as barreiras apodrecidas da sua própria língua" (BENJAMIN 2013: 117). Uma nova tradução pode, assim, trazer um novo fôlego para a língua materna do tradutor, novas formas de ver as questões que ela carrega, outras possibilidades para se encarar o destino e a justiça.

\section{Uma teoria do romance entre traduções}

Ao resenhar a recente tradução de um romance para sua língua, Benjamin desenvolve também algumas de suas reflexões a respeito de narração e destino, vida e romance. Para exemplificar a dificuldade de produzir coerência em textos nem sempre homogêneos, explorando a problemática da historicidade das traduções, proponho uma pequena análise e discussão crítica de uma dificuldade em que esbarrei ao traduzir esse texto de Benjamin, “Am Kamin” [À lareira]. Trata-se de uma pequena recensão crítica de um romance do escritor inglês Arnold Bennet, The Old Wives Tale, publicado na Inglaterra em 1908, após o lançamento de sua primeira tradução para o alemão em 1932. Aí Benjamin desenvolve uma pequena teoria do romance, comparando o desenrolar da narrativa para o leitor à chama que queima em uma lareira: "se o romance é uma construção, o é muito menos no sentido do arquiteto, que no da empregada que empilha a lenha na lareira. Não deve ser duradouro, mas deve queimar bem". 
CARDOSO, R. - Historicidade da tradução em Benjamin

Além das dificuldades de traduzir um texto de Benjamin por suas formulações muito sintéticas, uso de metáforas, ordens inversas, uso alternado de períodos longos e muito curtos, a referência a termos e conceitos da crítica da época e da filosofia, a densidade da argumentação e das imagens, um problema bastante específico se colocou nesse texto particular. Como traduzir as citações que Benjamin faz do romance de Bennet, citações da tradução para o alemão dos anos 1930, de um texto inglês de 1908 emulando um narrador do início do século XIX.

Pese, ainda, para o problema em questão, que o livro de Bennet não possui, até hoje, uma tradução para o português. Não que a existência dessa tradução facilitasse necessariamente o trabalho. Isto porque, além da dificuldade em encontrar os trechos correspondentes no romance de mais de 500 páginas, Benjamin se utiliza das descrições e termos do texto em alemão para desenvolver seus argumentos. Assim justifica-se, a princípio, a escolha por traduzir os trechos para o português diretamente da tradução alemã citada por Benjamin, o que, no entanto, produziu alguns efeitos estranhos quando cotejei os trechos com o texto original em inglês. Por exemplo, ao encontrar em uma das citações:

deswegen ist ihre Atmosphäre so schwarz wie der Schmutz und Dreck auf ihren Straßen; traduzi literalmente a expressão fixa "Schmutz und Dreck", comum em alemão, por:

por isso sua atmosfera é tão negra quanto a poeira e a sujeira em suas ruas;

Voltando ao inglês, encontramos um simples:

for this its atmosphere is as black as its mud.

Carregando o desdobramento do qual o tradutor alemão se utilizou para fazer o texto soar natural em sua língua, a retradução em português acabou se afastando ainda mais da simplicidade e objetividade do original, transformando, justamente, a atmosfera descrita no texto, que seria tão bem caracterizada pelo português lama. Este simples exemplo permite entrever o tipo de dificuldades e aberrações geradas por traduções indiretas, muito comuns no Brasil em meados do século XX, hoje cada vez mais incomuns devido ao aumento no número de tradutores qualificados em diversos idiomas.

Uma outra citação apresenta dificuldades por sua conexão mais íntima com o argumento teórico do texto. Benjamin cita Bennet:

"Sie hatte überhaupt nichts vom wirklichen Leben gehabt" 
CARDOSO, R. - Historicidade da tradução em Benjamin

A frase, relativamente simples, revela algum estranhamento na tradução para o português. Uma primeira tentativa, mais literal, poderia dar em; "Ela não havia tido nada de uma verdadeira vida". A frase é compreensível, mas, com o ritmo pesado, a grave aliteração "verdadeira vida" e o pretérito mais-que-perfeito composto ("tivera" não seria de grande ajuda), é difícil imaginar a sequência como a fala de uma das personagens dentro do romance. Uma das dificuldades está em traduzir überhaupt, cuja função é enfatizar a negatividade do nichts. A frase tem um lugar-chave no texto de Benjamin pois enseja o argumento teórico a respeito da natureza do romance e sua relação com a vida, que encerra o texto.

Am Kamin, faz parte de uma série de textos em que Benjamin esboça sua teoria do romance. Como esclarece Detlev Schöttker (2006), essa teoria, que ocupou o pensador alemão do final dos anos 1920 a meados dos 30, foi sendo desenvolvida em diversos textos críticos e cartas, culminando com "O narrador. Observações sobre a obra de Nikolai Leskov" publicado em 1936, mas ainda guardando sua importância em textos posteriores. Nesses textos Benjamin procura esclarecer sua ideia da oposição entre narrador e romancista e sua preferência pelo primeiro que, no entanto, não pode ter mais espaço na sociedade moderna alienada pelo capitalismo. Schöttker demonstra como a teorização de Benjamin caminha paralela a de diversos críticos que pensam o romance na mesma época, mas delas se diferencia. Se formalistas russos como Eichenbaum ou escritores como Döblin valorizam a penetração da oralidade na escrita como marca do romance moderno ou necessidade do realismo, Benjamin ressalta a oposição entre oralidade e escrita que funda essa tradição, atentando para as condições sociais de sua produção e consumo enquanto uma mídia específica (SCHÖTTKER 2006: 559; 561), conduzindo ao declínio de formas de sociabilidade, como a da narrativa oral na modernidade. Se Lukács entende o isolamento do autor, e do herói do romance como uma das causas de sua ascensão, em "Am Kamin", Benjamin o atribui também à solidão do leitor.

Schöttker pondera o pessimismo presente em "O narrador", relativo ao declínio da experiência, com uma certa abertura ao novo, confrontando o mesmo fenômeno, presente em "Experiência e Pobreza". Se no primeiro texto o declínio da narrativa acompanha o declínio da experiência e da sabedoria, o último percebe a nova situação como uma oportunidade para construir o novo a partir das ruínas, sem precisar prestar 
CARDOSO, R. - Historicidade da tradução em Benjamin

contas a uma tradição bárbara. Uma nova pureza a partir da ausência de experiências (SCHÖTTKER 2006: 559).

Frequentemente "O narrador" é lido como o núcleo da teoria do romance de Benjamin, e se enfatiza seu pessimismo com relação ao romance, que excluiria assim a possibilidade do conselho, da transmissão da experiência, da sabedoria. Mas o contato com os outros textos sobre o assunto, e a presença recorrente de textos de prosa modernos nos textos de Benjamin permitem questionar essa suposta condenação do romance por Benjamin. Em "A crise do romance. Sobre Alexanderplatz de Döblin" Benjamin repete a separação entre os tipos ideais daquilo que chama romance puro, e a narrativa épica, em que se estabelece uma coesão entre linguagem e a vida do povo.

No poema épico, o povo repousa, depois do dia de trabalho: escuta, sonha e colhe. O romancista se separou do povo e do que ele faz. A matriz do romance é o indivíduo em sua solidão, o homem que não pode mais falar exemplarmente sobre suas preocupações, a quem ninguém pode dar conselhos, e que não sabe dar conselhos a ninguém. Escrever um romance significa descrever a existência humana, levando o incomensurável ao paroxismo. (BENJAMIN 1985: 54)

Tomando a teoria do roman pur de André Gide, que encontraria seu maior exemplo em Flaubert, Benjamin afirma que se trata aí de uma "interioridade pura, [que] não conhece a dimensão externa e constitui, nesse sentido, a antítese mais completa da atitude épica pura, representada pela narrativa" (BENJAMIN 1985: 56). Entretanto, retomando uma alegoria a que alude no começo do ensaio, Benjamin compara o romance ao mar e afirma que há aí um sal que o torna durável, não no tempo, mas no leitor: "Acontece com o sal épico o mesmo que com o sal químico: ele torna mais duráveis as coisas às quais se mescla [...] O verdadeiro leitor lê uma obra épica para 'conservar certas coisas" (BENJAMIN 1985: 59). Também em Am Kamin, Benjamin afirma que a "construção" do romance não é feita para durar. Mas, em ambos os casos, há algo, uma impureza presente no romance que traz ainda em si uma experiência transmissível, um conselho que perdura.

Em “Am Kamin”, como em "O narrador”, Benjamin repete o argumento de que todos os personagens do romance encontram uma morte, senão textual, simbólica, com o fechar do livro ao fim da leitura. Esse contato com a morte funciona, para o leitor moderno, como uma contraposição e um complemento ao recalcamento e ocultamento da morte que caracteriza a sociedade moderna. Mas, embora a vida de um personagem de romance se organize em função de sua morte na narração, ela ainda assim é capaz de transmitir calor e vitalidade, em seu desenrolar, ao leitor.

Pandaemonium, São Paulo, v. 22, n. 36, jan.-abr. 2019, p. 30-50 
CARDOSO, R. - Historicidade da tradução em Benjamin

$\mathrm{Na}$ frase em questão (“Sie hatte überhaupt nichts vom wirklichen Leben gehabt”), é notável o uso, pelo tradutor, do adjetivo wirklichen - wirklichen Leben, vida real, efetivamente uma vida, uma vida de fato, ou de verdade. A personagem nunca viveu uma vida de verdade, diz uma das duas irmãs, personagens principais do romance, a respeito da outra. "Ela nunca viveu realmente". Uma afirmação que extrapola a simplicidade do seu sentido no contexto do texto crítico e teórico de Benjamin. A vida fictícia da personagem que, entretanto, parece ter uma relação efetiva com a vida real do leitor. Um leitor de romances cuja solidão e isolamento corresponderia a uma vida não vivida, à falta de experiências. E a frieza dessa solidão aquecida pela vida que se consome no livro. Duas vidas não-vividas incendiadas quando colocadas em contato. A frase, aqui, soa quase como um desafio ao leitor. A inquietação nos leva a buscar a frase no texto original. (Uma busca difícil, diga-se de passagem: usando o recurso do livro eletrônico, sem saber a forma da frase em inglês, tive que procurar todas as ocorrências da palavra "life" no livro.):

\section{Hers had not been a life at all.}

A simplicidade da frase em inglês ainda assim resiste à tradução para o português. A ênfase dada pelo alemão überhaupt servira para caracterizar a negativa do inglês at all. Literalmente: "a sua não tinha sido uma vida, de todo" - uma monstruosidade suspeita. O fato é que se trata de uma frase simples, grave, mas corriqueira, na boca da personagem. Aos seus olhos a irmã nunca teve, de fato, uma vida completa, não gozou da vida como deveria. Posto simplesmente: "Ela nunca teve uma vida de verdade". Se a frase abre mão de reconstruir uma atmosfera arcaizante, remetendo-nos à fala mais formal e circunspecta que frequentemente atribuímos ao século XIX, ela se adequa à cotidianidade e ao peso da afirmação. Vale observar que o inglês não apresenta o verbo ter (she never had a real life). A vida da personagem ausente é simplesmente caracterizada como uma não-vida. Mas sustentamos, por outro lado, a presença do verbo na tradução alemã usada por Benjamin ("Sie hatte nichts vom wirklichen Leben gehabt").

Se a forma do romance, como oposição à épica e à narrativa, concretiza, no limite, a baixa nas ações da experiência que caracteriza a modernidade, nem sempre ela se manifesta em sua pureza ideal. Benjamin lamenta a incapacidade do romancista, e do homem moderno, que é tanto o leitor do romance quanto seu objeto, de receber conselhos. Sua mudez e sua surdez para a sabedoria. Mas esse silêncio não é absoluto. O momento sem sentido do romance - quando Bieberkopf perde seu braço ou Mietze é assassinada 
CARDOSO, R. - Historicidade da tradução em Benjamin

em Berlin Alexanderplaz - carrega alguma sabedoria. "Pois essa é a lei da forma romanesca: no momento em que o herói consegue ajudar-se, sua existência não pode mais ajudar-nos" (BENJAMIN 1985: 60). Assim também quando a irmã observa o destino da outra, morta, no romance de Bennet - o temor e o testemunho de uma vida não vivida. Talvez se possa falar da catarse como reconhecimento no momento trágico de que fala Aristóteles. Se o romance se consome no fogo que aquece a vida do leitor, nem tudo se perde. Dispersa ou perdida em meio a um mar de signos, sobrevive algo da narrativa, aí ainda se pode transmitir alguma experiência. Depois que se fecha o livro e morrem os personagens, algo ainda perdura no leitor, ele recebeu seu conselho.

Todo esse debate poderia ser enriquecido se houvesse uma tradução de "The old wives tale" para o português. O texto criaria vínculos mais fortes com a nossa língua e a nossa história e cultura. Como afirma Seligmann-Silva:

A história das traduções de um país aponta para a história da sua Bildung; indica a sua capacidade de 'saída' de 'si', sendo que a 'volta a si' implica na construção do vocabulário comum que está na base de toda cultura. O próprio ser da cultura só existe nesse movimento pendular (SELIGMANN 1998: 28)

A construção desta tradição não se fecha na história de sua língua, como se estivesse isolada em uma relação homogênea entre povo falante e estado-nação. Ela é uma prática social que instaura um hibridismo, aproximando simbolicamente culturas diferentes. O tradutor, dessa forma, é também um ser híbrido. Como escreve Homi Bhabha: "é vivendo na fronteira da história e da língua, nos limites de raça e gênero, que estamos em posição de traduzir as diferenças entre eles, numa espécie de solidariedade" (2014: 272).

A construção desta tradição é, ainda, tarefa de historiador, que busca na história textual de outras línguas um texto que se revele pertinente para sua contemporaneidade, e é carregada de uma responsabilidade também política. Vale lembrar as teses sobre a história de Benjamin:

Articular historicamente o passado não significa conhecê-lo 'como ele de fato foi'. Significa apropriar-se de uma reminiscência, tal como ela relampeja no momento de um perigo. [...] Em cada época, é preciso arrancar a tradição ao conformismo, que quer apoderar-se dela. (BENJAMIN 1985: 224)

As teorizações de Benjamin resistem a uma sistematização única e coesa. A constelação de noções e conceitos que as permeiam, no entanto, permanece como um signo que nos auxilia constantemente na tarefa de interpretar seus textos. Apesar das diversas transformações sofridas por seu pensamento, há aí, quando se debruça sobre 
CARDOSO, R. - Historicidade da tradução em Benjamin

questões que se aproximam de uma metafísica da linguagem ou de tradução, ou ao analisar o desenvolvimento de novas mídias na sociedade industrial, uma preocupação com a chegada de uma justiça, seja simbolizada por um messias ou representada pela revolução. A tarefa do tradutor, nesse sentido, também não escapa dessa preocupação. Possivelmente, nas teses "Sobre o conceito de história" se encontre a melhor expressão para a historicidade da tradução e a forma de sua relação com o original: a da imagem dialética, a "imagem que relampeja irreversivelmente", a tradução como a oportunidade encontrada no presente e um tigre que salta ao passado, ou de uma língua para outra. Assim, entre o encontro com a língua adâmica na tradução entre todas as línguas e a "porta estreita pela qual podia penetrar o Messias", talvez se possa pensar na tradução, em sua relação com a história, como um salto dialético entre as línguas.

\section{Referências bibliográficas}

ANDERSON, Benedict. Comunidades imaginadas: reflexões sobre a origem e a difusão do nacionalismo. Trad. de Denise Guimarães Bottman. São Paulo: Companhia das Letras, 2008.

BENJAMIN, Walter. "Das Glück des antiken Menschen"; "Sokrates"; "Trauerspiel und Tragödie". In: TIEDEMANN, Rolf; SCHWEPPENHÄUSER, Hermann (Org.). Gesammelte Schriften II, 1 . Frankfurt: Suhrkamp, 1972, p. 126-137.

. “Am Kamin”. In: Gesammelte Schriften III. Frankfurt: Suhrkamp 1973, p. 388-392.

. "A Crise do Romance. Sobre Alexanderplatz, de Döblin". In: BENJAMIN, Walter. Magia e técnica, arte e política. Trad. de Sérgio Paulo Rouanet. São Paulo: Brasiliense, 1985.

. Escritos sobre mito e linguagem. Trad. de Susana Kampff Lages e Ernani Chaves. São Paulo: Duas cidades; Ed 34, 2013.

BERMAN, Antoine. A prova do estrangeiro. Trad. de Maria Emília Chanut. Bauru: EDUSC, 2002.

BHABHA, Homi. "DissemiNação". In: BHABHA, Homi. O Local da Cultura. Belo Horizonte: Editora UFMG, 2014.

DERRIDA, Jacques. Torres de Babel. Trad. de Junia Barreto. Belo Horizonte: UFMG, 2002.

FARACO, Carlos A. Linguística Histórica, uma introdução ao estudo da história das línguas. São Paulo: Ática, 1998.

GAGNEBIN, Jeanne Marie. "Origem, original, tradução" In: GAGNEBIN, Jeanne Marie. História e Narração em Walter Benjamin. São Paulo: Perspectiva, 2013.

LAGES, Susana Kampff. Walter Benjamin, tradutor de Baudelaire. Alea, v. 9, n. 2, jul-dez 2007, p. 239-249.

LUTHER, Martin. "Sendbrief vom Dolmetschen (1530) / Carta aberta sobre tradução". Tradução de Mauri Furlan. In: Clássicos da teoria da tradução - Antologia bilíngue, vol. 4, Renascimento. Florianópolis: UFSC/NUPLITT, 2006, p. 94-119.

“Observações”. In: A Bíblia de Jerusalém. São Paulo: Paulus, 2006. p. 13-16.

Seligmann-Silva, Márcio. Filosofia da Tradução e tradução de filosofia - o princípio da intraduzibilidade. Cadernos de Tradução, v. 1, n. 3, 1998, p. 11-47.

Pandaemonium, São Paulo, v. 22, n. 36, jan.-abr. 2019, p. 30-50 
CARDOSO, R. - Historicidade da tradução em Benjamin

SCHÖTTKER, Detlev. “'Der Erzähler. Betrachtungen zum Werk Nikolai Lesskows"”. In: LiNDNER, Burkhardt (org.). Benjamin Handbuch. Stuttgart: J. B. Metzler, 2006, p. 557566.

WeBer, Max. A ética protestante e o "espirito" do capitalismo. Trad. de José Marcos de Macedo. São Paulo: Companhia das Letras, 2004.

\section{Anexo}

À lareira.

Sobre o Jubileu de 25 anos de um romance ${ }^{4}$ Walter Benjamin

Conta-se a respeito de Oscar Wilde: Encontrava-se certa vez rodeado de pessoas, e a conversa era sobre o tédio. Cada um tinha seu pequeno bordão; Wilde manteve-se calado até que o último houvesse falado. Olharam-no com expectativa. Então ele disse: "Quando me entedio, então pego um bom romance, sento-me à lareira e observo o fogo."

De fato, essas duas coisas combinam bem: um fogo abrasador de lareira e um romance aberto. E porque temos agora um nas mãos - agora, 25 anos após sua primeira publicação, a principal obra de Bennet foi traduzida -, queremos, sem fechá-lo, lançar um olhar ao fogo da lareira. Ninguém é tão desprovido de fantasia, que não lhe ocorra algo olhando para a lareira. Queremos ver, pois o espetáculo que ela revela é, para nós, análogo a um romance. O leitor de romances o considera de uma maneira diferente daquele que mergulha em um poema ou que segue um drama. Ele é especialmente solitário, diferentemente não apenas do homem em público, mas também daquele que lê um poema. Um está envolto na massa e participa de sua tomada de posição, o outro está pronto a voltar-se para um parceiro e emprestar sua voz ao poema. O leitor do romance está sozinho, e por um bom tempo. Não apenas isso: nessa solidão ele se apossa de seu material mais ciosamente, mais exclusivamente que os outros dois. Ele está pronto a tomá-lo como se fosse seu, sem deixar rastros, e mesmo a formalmente consumi-lo. Pois ele aniquila, ele devora o material como o fogo devora a lenha na lareira. A emoção transmitida pela

\footnotetext{
${ }^{4}$ Arnold Bennett, Konstanze und Sophie oder Die alten Damen. ([Roman.] Aus dem Englischen übers. von Daisy Brody.) 2 Bde. München: R. Piper u. Co. (1932). 414 S., 459 S. (o original em inglês, The old wives tale, pode ser encontrado em http://www.gutenberg.org/ebooks/5247 (13/03/2018))
}

Pandaemonium, São Paulo, v. 22, n. 36, jan.-abr. 2019, p. 30-50 
CARDOSO, R. - Historicidade da tradução em Benjamin

obra assemelha-se bastante à corrente de ar que anima as chamas na lareira, e que dão vida ao seu jogo.

Esta alegoria revela uma imagem diferente daquela que se quer enxergar normalmente no debate sobre o romance como um gênero. Este debate deriva, na Alemanha, de Friedrich Schlegel. Desse modo, não ficou sem consequências que ele tenha se recusado a reconhecer, no romance, outra coisa que uma forma de arte - as formas de um Cervantes ou de um Goethe - e de maneira alguma o fundamento mais amplo do épico. O romance compartilha esse fundamento com a narrativa (Erzählung), e ele emerge principalmente nos ingleses: Scott, Dickens, Thackeray, Stevenson e Kipling, ainda que romancistas, eles são, antes de tudo, narradores. O narrado flui através deles para o livro, e flui também dele de volta como história (Geschichte). Flaubert, por outro lado, que encarna nesse aspecto o adversário, deve ter lido frequentemente suas frases em voz alta para si mesmo: a completude rítmica que ele quis a tal ponto explorar, encerra o leitor como que à prova de som no interior de sua grandiosa obra. Nelas, de fato, frase se debruça sobre frase como pedra sobre pedra em uma obra de alvenaria. Não foi preciso mais para pôr em curso - muito para o benefício de sua exigente impotência - a mística da "construção" com a sua reverberação de "prosódia" sonora. Mas se o romance é uma construção, o é muito menos no sentido do arquiteto, que no da empregada que empilha a lenha na lareira. Não deve ser duradouro, mas deve queimar bem.

No espaço de mais de cinco décadas, Bennett colocou os acontecimentos em camadas. Com a mesma frouxidão, erigem-se no mesmo espaço as gerações umas sobre as outras: três. E estas descansam docilmente sobre as cinzas das predecessoras. Era gente de negócios que habitava as Five Towns. Por cinco décadas, sua estirpe se encarnou em duas irmãs, a mais jovem das quais morrerá sem filhos, enquanto a mais velha deixará apenas um amável e mimado herdeiro das duas fortunas. As Five Towns, onde têm o seu berço e, igualmente, seu leito de morte, são essencialmente "únicas em seu gênero. Do norte ao sul do condado, apenas elas representam civilização, ciência aplicada, métodos de fabricação organizada e todo o século, até você chegar a Wolverhampton. Elas são únicas e indispensáveis, porque sem as Five Towns não se poderia beber chá em xícaras, sem sua ajuda não se poderiam comer as refeições com decoro. Por isso a arquitetura das Five Towns é uma estrutura de fornos e chaminés; por isso sua atmosfera é tão negra quanto a poeira e a sujeira em suas ruas; por isso cheira e queima a noite toda, de modo que Longshaw a pôde comparar às vezes com o inferno.” Bennett não dá a conhecer esse 
CARDOSO, R. - Historicidade da tradução em Benjamin

inferno da mesma forma que Dickens torna visível o inferno da Londres no início da industrialização em Loja de Antiguidades [The Old Curiosity Shop; em alemão Der Raritätenladen]. A existência de suas duas irmãs é vedada contra esse inferno; se ele não o diz, torna-o visível ao fazê-las crescer em uma loja de tecidos, para a qual as duas já estavam destinadas desde o princípio. A que preço a mais jovem escapa depois dessa determinação, e quão semelhante parece ser a força que a jovem arranca dessa casa e que finalmente a arruína. Então, próximo ao fim do romance começa a transformar-se o semblante da cidade, na qual o pai a fundara. A forma de existência (Daseinsform) na qual trabalho e prazer se equilibram na balança, o negócio rentável, a vida digna de ser vivida, se extinguem. A sombra das corporações e trustes começa a assombrar as Five Towns; no início do século, concorrentes que entravam em campo com banners, gramofones e preços baixos fizeram recuar os antigos comerciantes. A vida das irmãs se passa em um período de transição. Uma, a mais velha, ainda é fiel à tradição, assume a loja, traz seu filho ao mundo e guarda a casa na qual acolhe a irmã que retorna treze anos mais tarde.

Essa casa é um caso particular. Ela é o colo onde se formou a riqueza da família. Gradualmente, ao longo de décadas, transformou-se de três apartamentos em um único labirinto, no qual salas de negócios, lojas e alojamento se fundiram em uma construção, que não oferece muito conforto, mas oferece o hábito inabalável. Nessa casa o narrador exercitou a suas mágicas pinceladas poéticas, das quais o romance é tão rico. Ela é, fundamentalmente, a despeito dos dias fatídicos que aguardam as duas mulheres, nada mais que o lugar onde as vidas das duas irmãs e de ambas as velhas senhoras, de maneira estranha, dificilmente distinguível, entram em jogo e se entrelaçam. "A sensação de vasta escuridão daquelas regiões inferiores, uma escuridão que se iniciou no andar de cima, na escada da cozinha, e que terminava nos ângulos invisíveis da despensa ou, ainda, ignorando todos os corredores, no cotidiano da Brougham Street - essa sensação singular que Constance e Sophie adquiriram nos seus anos de infância, as acompanhou quase sem atenuar-se até a idade avançada."

É um material seco, do qual se alimenta o interesse ardente do leitor. O que quer dizer isso? "Um homem que morre aos trinta e cinco" disse certa vez Moritz Heimann, "é, em cada ponto de sua vida, um homem que morre aos trinta e cinco." Não sei se isso é certo; acredito e espero que seja falso. Mas, no romance, é completamente correto; realmente não se pode descrever a essência do personagem de romance melhor do que 
CARDOSO, R. - Historicidade da tradução em Benjamin

com essa frase. Ela afirma que o sentido de sua vida abre-se apenas a partir de sua morte. O leitor, entretanto, vê no romance personagens nos quais ele lê o "sentido da vida". Ele deve estar avisado, a partir daí, de uma forma ou de outra, de que experienciará sua morte. Essencialmente, apenas no sentido metafórico: o final do romance; mas, mais precisamente, na realidade. Como dão a entender que a morte já aguarda por eles, e de uma forma bem determinada, e em um lugar bem determinado? Essa é a questão que conjura o leitor tão irresistivelmente ao seu romance como aquela chama da lareira faz com a lenha. Na verdade, ele se torna idêntico à morte, e lambe os protagonistas assim que possível; como línguas de fogo que brincam em torno de um galho, antes que ele finalmente se incendeie.

Deve tornar-se cinzas. Por isso o livro, que se inicia com os tempos de menina das irmãs, se chama, ainda assim, "a história das velhas senhoras”. Bennet conta em uma introdução que, infelizmente, para os alemães, não está traduzida, como lhe ocorreu a ideia dessa obra, antes de começar a trabalhar nela, ao ver, certa vez, uma velha senhora entrando em seu café parisiense favorito. Ideias, como as que a triste aparição da senhora despertou nele, qualquer um pode ter. Mas nele essas ideias se tornaram a origem de uma vida tão poetizada, que nada delas se perdeu.

"Ninguém", afirma Pascal, "morre tão pobre que não deixe nada para trás." Também em recordações - mesmo que elas nem sempre encontrem um herdeiro. $\mathrm{O}$ romancista assume essa herança. E raramente sem uma profunda melancolia. Pois o que a irmã sobrevivente diz da morta aqui: "Ela nunca teve uma vida de verdade", visa ser a suma do legado que cabe ao romancista. A morta vivenciara todo um destino amoroso ornado pela história mundial. Quão miserável é a imagem que o autor lhe atribui na recordação. Algumas vezes a que ainda vive o intui antecipadamente. "Algumas vezes, em um momento desocupado, sobrevinha-lhe o pensamento: 'Que estranho que eu esteja aqui, que eu faça agora o que eu estou fazendo!' Mas o correr regular de sua vida a tragava rapidamente consigo. Ao final do ano de 1878, o ano da exposição, sua pensão já atingia os dois andares em vez do único do início."

A obra se divide em quatro livros; o último é intitulado "O que a vida traz". E os dois últimos capítulos deste se chamam "O fim de Sophie" e "O fim de Constance". De todos os dons que o romance traz, este é o mais certo: o fim. Os romances não precisam necessariamente dizê-lo. Não é porque nos apresenta um destino estranho que o romance é significativo, mas porque este destino, sob as chamas que o consomem, nos fornece o 
CARDOSO, R. - Historicidade da tradução em Benjamin

calor que de nosso próprio destino nunca ganharíamos. O que sempre faz com que o leitor a ele retorne, é seu dom mais misterioso, aquecer com a morte uma vida tiritante.

Recebido em 13 de março de 2018 Aceito em 05 de agosto de 2018 